\title{
Alphabets and "Calligraphy" in the Section on Prayers, Special Characteristics of the Quran and Magic Squares in the Inventory of Sultan Bayezid II's Palace Library
}

\author{
Guy Burak \\ Librarian for Middle Eastern, Islamic and Jewish Studies, Elmer Holmes Bobst Library, \\ New York University, New York, NY, USA \\ guy.burak@nyu.edu
}

\begin{abstract}
This essay is an attempt to read the section on invocations, prayers, the unique qualities of the Quran and magic squares of the palace library of the Ottoman Sultan Bayezid II (d. 918/1512) along with several works by 'Abd al-Rahmmān al-Bisțāmī (d. c. 858/1454 or 1455) to cast light on underexamined perceptions of calligraphic styles and alphabets/scripts employed to inscribe talismanic objects and manuscripts. Methodologically, the intention is to situate the inventory of the palace library in the intersection of prescriptive texts, on the one hand, and talismanic objects and manuscripts of invocations, on the other. By taking the inventory as a document of practice, the essay seeks to illustrate the importance of paying attention to other elements of the talismanic compound in general, and to the use of alphabets/scripts with their specific talismanic attributes in particular.
\end{abstract}

Keywords

alphabets - libraries - talismans - lettrism - Kufic script - calligraphy - Ma'qilī script - 'Abd al-Raḥmān al-Bisțāmī

1

Introduction

Even a cursory overview of the inventory of the palace library of the Ottoman Sultan Bayezid II (d. 918/1512) reveals that the section on invocations, the special qualities of the Quran and magic squares stands out. As opposed to other sections in the inventory, in addition to volumes, the section contains a fairly large number of inscribed objects: talismanic shirts, skullcaps, amulets of different types and shapes. The Sultan's librarian, 'Atufi, also pays unusual attention to the objects' shapes and materials they were made of. Moreover, and most importantly for this essay, he cares to mention the "calligraphic" style in which the objects were inscribed or to mention the identity of the calligrapher: "the Beautiful Names in Kufic script," "invocations in Yāqūt's [al-Musta'șimī (d. 697/1298)] hand (hatt)," "the supplication of the morning and the supplications of the seven days [of the week] in Argiun's [al-Kāmilī (active first half of the fourteenth century)] hand," "the Litany of the Sea [al-Šādilil’s Hizb al-baḥr] written in single [or cutout] letters (hatt muqatta)" (Burak, 2019). This descriptive approach was not employed across the inventory (the exception being the section on the copies of the Quran), despite the fact that other sections contained exquisite manuscripts, some of which 
were produced by accomplished calligraphers (Atbaş, 2019). In a recently published chapter (Burak, 2019), I have tried to offer several explanations to these unusual characteristics of this section. Specifically, I have proposed that 'Atufi's interest in the identity of the calligraphers stemmed from Sultan Bayezid II's own interest in calligraphy and the prominence of these calligraphers in the calligraphic tradition of the Islamic East. While I still think that these are plausible explanations, in this essay I would like to offer a different interpretation of 'Atufi's interest.

The descriptive practices employed throughout the section on invocations, the special qualities of the Quran, the Beautiful Names of God and magic squares, I would suggest, are derived from a particular understanding of the "talismanic compound." My interest in the "talismanic compound" is inspired by the thirteen-century Andalusian mystic and scholar Muhyī al-Dīn Ibn al-'Arabī's (d. 638/1240) treatise on the Arabic letters mìm, wāw and nūn. As he explains, "[i]t is incumbent upon those who attempt such things [i.e., letter magic] that they have knowledge of the compound (tarkib) together with its forms, times, alphabets/scripts (aqläm), and so forth; if even the slightest aspect is off, the whole operation will come to nothing" (Melvin-Koushki, 2012: 199). While a greater deal of attention has been paid to the written texts and to the lettrist/literalist theories (harfiya), much less attention has been devoted to other crucial elements of the "talismanic compound." Following Ibn al-'Arabī, I would like to read the section of the inventory by situating it at the intersection of theoretical and prescriptive texts dealing with the alphabets/scripts (qalam, pl. aqlām) and their talismanic attributes, on the one hand, and talismanic objects and manuscript copies of the titles mentioned in the section, most dating from the fifteenth through the sixteenth centuries, on the other. My reading is an attempt to identify connections between the librarian's sensibilities and those of practitioners who produced the objects and manuscripts.

My reading of the inventory, manuscripts and objects is also informed by several works authored by the fifteenth-century scholar 'Abd al-Raḥmān al-Bisțāmī (d. c. 858/ 1454 or 1455), an eminent member of one of the intellectual networks that spanned the Islamic East in the fifteenth century, the Brethren of Purity (Binbaş, 2016). In particular, I would like to closely examine his work on the alphabets/scripts titled The Pleasures of the Knowledgeable on the Methods of the Alphabets of What the Messenger of Wisdom Encountered in the Treasures of Mercy (Mabāhiğ al-alām fì manāhiğ al-aqlām mimmā alqāhu rasül al-hikma min hazǟin al-rahmma). This work may be situated in a broader, not fully mapped out, corpus on the attributes of alphabets/scripts, a corpus that has received very little scholarly attention. ${ }^{2}$

Bisțāmī is a convenient guide as he ties together the inventory of the palace library, the prescriptive texts and the territories from which the manuscripts and objects hailed. Born in Antioch, Bisțāmī's biography spans the Mamluk and the Ottoman domains. After his arrival to Cairo, he was initiated into a scholarly fraternity, whom he addressed in his writings as "the Brethren of Purity and Friends of Fidelity" (ihwwān al-șafă wa-hullān al-wafā̉). Other members of this network, much like Bisțāmī himself, became influential in the courts of the Islamic East in the late fourteenth and early fifteenth centuries. It was in the learning centers of the Mamluk sultanate that Bisțāmì gained his reputation as an expert in the science of letters and God's Beautiful Names ('ilm al-hurüf $w a-l-a s m \bar{a})$. In the early years of the fifteenth century, following the devastating consequences of Tīmūr's (d. 808/1405) excursions in Anatolia, Bisțāmī traveled to what remained of the Ottoman polity, where he became the teacher of the jurist and military judge to the Ottoman prince Mūsā (d. 816/1413), Shaykh Badr al-Dīn (d. 823/1420). In 819/1416, after an unsuccessful millenarian rebellion Badr al-Dīn had led, ${ }^{3}$ Bisțāmī fled to the Mamluk sultanate. Several years later, as the protégé of Şeyhülislam Molla Fenari (d. 834/1431), he returned to Bursa, where he spent the last three decades of his 
life. In recent years, several studies have explored different aspects of Bisțāmī's thought and that of other members of his network. ${ }^{4}$

His influence over the course of the fifteenth and the sixteenth centuries has been well studied. As Cornell Fleischer has pointed out, Bisțāmīs own work, and particularly his Key to the Comprehensive Prognostication (Miftāh al-ğafr al-ğämi'), circulated widely in the Ottoman imperial and princely courts (Fleischer, 2009: 238-9). Moreover, Bisțāmì's view of the classification of the sciences had a profound influence on the palace librarian, 'Atufī. In addition, an autographed copy of Bisțāmī's Perfumed Fragrances on the Meccan Openings (al-Fawāih al-miskīya fì al-fawātih al-Makkīya), his encyclopedic summa in which he lays out his classification of the sciences, was included in Bayezid II's library and bears the Sultan's seal (Fleischer, 2019: 155-6o). Indeed, as we shall see, ideas found in Bisțāmì's writings may have informed the production of some of the manuscripts and objects which were included in this section of the inventory and the palace librarian's descriptive practices.

Several comments on my methodological choices in this essay are in order. Firstly, and most importantly, the essay is somewhat conjectural. In some instances, readers looking for conclusive evidence may be disappointed. My reading seeks to follow the logic I find in certain texts and documents (such as the inventory and Bisțāmī's treatises) and tries to interpret objects and other texts in its light. I do not intend this reading to be conclusive (an impossible task, anyway) but a tentative hermeneutical exercise. It is quite difficult, perhaps impossible, to determine the extent to which every practitioner was aware of the theoretical and prescriptive writings. It is quite possible that the interpretation (and justification) of the same talismanic practice varied in different circles, in which case, the inventory reflects one of several - competing or supplementary perceptions. Nevertheless, I would propose, the juxtaposition of the inventory, texts and objects may yield intriguing insights and I hope that future studies will corroborate or utterly refute my suggested conclusions.

The second comment concerns the corpus I will be examining in this essay. This essay takes the inventory of the palace library as its entry point to explore a web of textual and visual cross-references found across roughly contemporary manuscripts of the titles mentioned in the section, talismanic objects and prescriptive texts. The corpus of texts, manuscripts and objects is, admittedly, an approximation based on the palace library's inventory. "Approximation" because many of the titles and all of the objects listed in the inventory have not been identified. In addition, the prescriptive texts rarely point to a specific, identifiable object or manuscript. It is certain, however, that the palace library was home to texts (and possibly objects) originating from different parts of the Islamic East. Accordingly, most of the works and objects examined in this essay hail from the core lands of the Ottoman domains, the Mamluk sultanate and the Timurid and post-Timurid lands. Despite the vast geography, a remarkable degree of coherence is evident. Moreover, the focus on the inventory of the palace library does not mean that the production and consumption of these texts and objects was exclusively courtly, although the inventory clearly reflects the interest of rulers and sultans in them. Indeed, these texts and objects circulated well beyond the royal courts, as did many of the practitioners and thinkers who produced them, such as Bisțāmī.

As Bisțāmì makes clear in the Pleasures of Knowledge, for him, the study of the aqlām is part of the science of letters and names (Bisțāmī, 2016: 59-62).5 Accordingly, in his Perfumed Fragrances, where he lays out his classification of the sciences, Bisțāmī 
does not classify the study of the qualities of the alphabets as a separate science. Furthermore, in the introduction to his Pleasures, Bisțāmī relates that this work is a supplement (takmil) to a work on the science of letters and magic squares, titled The Sea of Methods of Acquaintance on the Science of Magic Squares and the Letters (Bahr al-wuqūf fì 'ilm al-awfāq wa-l-hurūf) (Bisțāmī, Princeton Ms). Therefore, the corpus on the secrets of the alphabets adds an important and integral dimension to the study of lettrist/literalist corpus and should be primarily read in this context. ${ }^{6}$

The talismanic attributes of the alphabets are the focus of several works and treatises, many of which, it appears, have not survived. Perhaps the best-known work in this corpus is the one falsely attributed to the tenth-century scholar Ibn Wahshìya (d. after 318/930), titled The Long-Desired Fulfilled Knowledge of the Signs of Alphabets (Shauq al-mustahām fì márifat rumūz al-aqlām) (Ibn Wahshīya, 2010). ${ }^{7}$ Despite some similarities between Bisțāmì's work and the Long-Desired Knowledge, it is unclear to what extent Bisțāmī was familiar with this earlier work. ${ }^{8} \mathrm{He}$ evidently consulted other works dealing with the alphabets: in his Sun of Horizons on the Science of Letters and Magic Squares (Šams al-äfāq fí 'ilm al-hurü f wa-l-awfäq), he refers to at least one work that, as its title suggests, deals specifically with the alphabets. ${ }^{9}$

\subsection{The Pleasures of the Knowledgeable on the Methods of the Alphabets of What the Messenger of Wisdom Encountered in the Treasures of Mercy}

Since the Pleasures has not received much attention in modern scholarship and due to its centrality to the argument of this essay, it is worth dwelling in greater detail on Bisțāmī's treatment of the alphabets in this work. The Pleasures consists of two parts $(k i t a \bar{b})$ and a conclusion. Importantly, there are significant discrepancies and inconsistencies (or, at least, so it seems to me) between the sections of the work. For example, different alphabets with similar names appear in different sections of the work. These inconsistencies make the task of offering a coherent account of Bisțāmī's Pleasures quite daunting.

In his authoritative article on Bisțāmī, Fleischer has listed several ideas that characterize Bisțāmī's oeuvre. Not all of these ideas are explicitly manifest in Bisțāmī’s cosmology of alphabets, but some key ideas are at play in the Pleasures: "Abrahamic prophets and pre-Islamic history as authoritative sources of guidance, particularly through appropriate application of either mystical, lettrist, or astrological techniques; reverence for the figure of Ali and his descendants as possessors of comprehensive gnostic knowledge of past and future history transmitted, though increasingly restricted in its possession and circulation, from Adam and the time of Creation; and particular reverence for Jesus and for Christian, as well as Jewish, wisdom traditions" (Fleischer, 2009: 235). The Pleasures also reflects the amalgam that "drew heavily on the late antique Platonic and Hermetic inheritances brought into Arabic in the Abbasid period, but was also shaped considerably by the bold claims of Muslim philosophers and mystics to penetrate the unseen" (Gardiner, 2019: 736).

At the core of the Pleasures lies a survey of a wide range of alphabets. Although not stated explicitly, it is evident that each of these alphabets has specific (talismanic) qualities and attributes. But first and foremost, the Pleasures is a treatise about writing as a cosmological act. In an introductory passage, Bisțāmī establishes a relationship between the Quranic divine "pen" (qalam) and human writing and penmanship:

Ibn 'Abbās said: God created the [Preserved] Tablet out of white pearl, and the pen out of green emerald. God Most High said: "Recite in the name of your Lord who created man from a clinging substance. Recite and your Lord is the most generous, who taught by the pen, [who] taught man that which he knew 
not." That is: He taught man that he wrote in [their] hearts. And Ibn Zubair read "penmanship" ( ilm al-hatt) in [the word] "pen."

Euclid said: The script/line is mental geometry (al-hatț handasa rūhānīya) that manifests through a bodily instrument (äla ğusmānīya). The line in the art of geometry [means] length without width, and whoever was given the wisdom was given great benefit.

Mujahid said: That is, the beautiful handwriting (al-hatț al-hasan).

[Mujahid] said: Or a cause by knowledge (ițāra min 'ilm).

Ibn 'Abbās said: That is, the beautiful handwriting.

BISṬĀMĪ, 2016: 33-4

A few lines later, Bisțāmī modifies the saying attributed to Euclid and explains that the script/line is a mental/spiritual organ (haia rūhānīya) that manifests itself through a bodily instrument. The letters, too, he continues, are a foundation (așl) of the spirit (rüh) and manifest themselves through the body's senses (hawāss al-ğism). Furthermore, he explains, the "script/line is derived $\left(m a^{\prime} h \bar{u} d h\right)$ from a circle (däira) which is the origin of all letters." The circle starts with alif, which serves as its pole/axis (qutb), from where the letters diverge around the alif, each of which with its own beneficial qualities (?), identification and purpose. ${ }^{10}$ The circle can be organized in different manners, which all correspond to already existing impressions in the soul (wa-idhā nazara ilā al-aškāl wajada lahā ințibā'an fíal-nafs qabla wuğūdihāfì al-taškīl). It is not fully clear to what soul Bisțāmī refers: it may be the practitioner's, or, perhaps more likely, a cosmological spirit. In any case, "if the letters [one writes] correspond to this circle," Bisțāmī elaborates, "the script is sound" ( fa-idhā nasabat al-ḥurüf tilka al-dāira șaḥha al-hatț) (Bisțāmī, 2016: 35).

The visual manifestations of the letters or the alphabets, then, are an integral element of the lettrist/literalist cosmology, a cosmology that is both manifest in and constituted by the act of writing and reading. Further, by breaking down the elements of writing (and reading), Bisțāmī identifies a specific faculty in each element and establishes the relationship between the different components: the author $(?)^{11}$ is the active faculty (qūwa fă ila); the "pen" (qalam) is/has instrumental faculty (qūwa ālìya); the ink (midād) has illustrative faculty (qūwa tașwiriña); the script/line (hatț) has depictive faculty (al-qüwa al-mușauwira); the written [text] has the carrying faculty (al-qüwa al-hāmila); eloquence (balāğa) has the increasing faculty (al-qūwa al-nāmīya); the diacritic dots (nuqaț) have a defining faculty (qüwa mu'arrifa); the case markings (i'rāb) are the clarifying faculty (qūwa mubaiyina); the reader has the manifesting faculty (qūwa muzahhira); and the listener has the knowing faculty (qüwa álima). In other words, for Bisțāmī, each element serves a different purpose or cosmological faculty and may have a different effect. He concludes this list by referring to a saying he attributes to the sage Balitas that "the pen [but also the alphabet] is the greatest talisman" (al-qalam al-tilasm al-akbar) (Bisțāmī, 2016: 35).

Fittingly, the final section of the introduction is dedicated to the relationship between the script/alphabet (hatt) and cosmological secrets. According to several savants ( ulamā’), whom Bisțāmī cites approvingly, the script/alphabet can unlock the secrets of existence (asrār al-wuğūd), the overt meanings and structures and the hidden secret. Furthermore, he elucidates:

Know that the written scripts/hands/alphabets (al-huțūt al-kitābìya) point (dalīl) to the uttered entity/substances (al-ma'āni al-qawlìya), and the spoken mental meaning points to contemplative entity/substances (al-ma'ānì al-fikrīya), and 
the contemplative entity/substances point to entity/substances of the thing itself (al-ma'ānì al-'ainīya).

BISṬĀMĪ, 2016: 35-6

This chain of relationships between writing, contemplation and the thing itself again situates writing in a cosmological order.

As I have already pointed out, most of the body of the Pleasures, which is divided into two books, is dedicated to surveys and taxonomies of different alphabets. The surveys are primarily intended to establish various connections between the different alphabets in an exercise that may be interpreted as an attempt to capture multiplicity within a single cosmology. ${ }^{12}$

In the first chapter (fașl) of the first book, Bisțāmī offers several classifications of alphabets. First comes the classification based on the direction of writing: certain alphabets, like Arabic, are written from right to left, while others, like Latin (?) (Rümūya), Greek and Coptic, are written from left to right. Alphabets can also be divided according to the connectedness of the script: in the alphabets written from right to left, the letters are connected (muttașala), while in those written from left to right, the letters are written separately (munfașala). Third is the division of the alphabets according to languages (luğāt). Each alphabet, according to Bisțāmī, has a circle (dā̉ira) that was revealed (nazzalūhā) for overt languages (luġāt bayānīya) and mental figures/forms (ashkāl rūhānīya). Bisțāmì pauses to inform his readers that the Arabic form (al-šakl $a l$-Arabì) is the most beautiful/best (ahsan). He concludes his taxonomy by saying that there are twelve alphabets that pertain to specific nations (kitābāt al-umam): Arabic, Himyarite, Greek, Persian, Syriac, Hebrew, Latin (Roman), Coptic, Berber, Andalusian and Indian (Bisțāmī, 2016: 41). The use of the Arabic root $n-z-l$ is noteworthy as it links alphabets to instances of revelation (not unlike the revelation of scriptures). The connection between alphabets and revelation is also related, as we shall presently see, to the attribution of alphabets to prophets.

Since Bisțāmī has already claimed that Arabic is superior to the other alphabets, he moves on to briefly narrate its history. As he has already related in the introduction, according to Ka'b al-Aḥbār, Adam was the first writer in Arabic. Then, after the flood, Ismāîl found Adam's alphabet. Ibn 'Abbās, whom Bisțāmī cites, offers a slightly different account. In this account, Ismāîl was the first to write in Arabic. Bisțāmī, however, includes alternative accounts concerning the first writers in Arabic, which exclude Ismāîl (Bisțāmī, 2016: 41-2). As will be discussed below, reconstructing the history, or at least tracing the origins of specific alphabets (and languages), is central to the corpus on the secrets of the alphabets in general, and to Bisțāmì's own writing on the topic in particular.

After three chapters where Bisțāmī discusses the science of letters, he turns in the fifth chapter of the first book to a series of taxonomies of the spiritual alphabets (al-aqlām al-rūḥānīya) according to their secretive attributes (sirr ḥurūfihā). This discussion can be seen as an attempt in comparative philology. First, he notes, all the alphabets, with the exception of Arabic, follow the abğad alphabetical order. Secondly, with the exception of Arabic, Syriac and Mongol (Mugulī), whose letters are connected, the letters of the remaining alphabets are separate (munfașal). Third, Greek (Yünānìya), Latin (?) (Rümīya) and Persian (Fārisīya) are written from left to write, whereas Arabic, Syriac and Hebrew are written from right to left. Here Bisțāmī adds a layer to the discussion in the work's first chapter: the direction of writing is significant as it connects certain alphabets to planetary orbits. The alphabets written from the left are aligned with the Great Orbit (al-falak al-azam), whose trajectory goes from East to West. The 
other alphabets are aligned with the orbit of the fixed stars (falak al-tawābit). He dubs the latter "the Berber/Barbarian alphabet" (qalam Barbarī) (Bisțāmī, 2016: 67).

Syriac occupies a special place in Bisțāmī's account, and he identifies some parallels between Arabic and Syriac: "There is no difference between Arabic and Syriac in terms of the order of the alphabets, and the attributes/descriptions of the Syriac letters [corresponds] to the Arabic alphabet" (wa-lā farqa baina al-'Arabì wa-l-Suryānī fì al-hijā' wa-hādihi șifat ḥurūf al-Suryānī 'alā hurūf al-mu'ğam) (Bisțāmī, 2016: 67). Syriac, however, is important in his cosmology of scripts as, according to one account, it is the first alphabet, from which the other alphabets evolved/diverged.

But as one keeps reading the Pleasures, one comes across an alternative account. Citing the ninth-century mystic Dū al-Nūn al-Mișrī (d. 245 or 248/859 or 862) ${ }^{13}$ Bisțāmì explains that the origin of all the alphabets of all the nations stems from a single alphabet, which is "the natural alphabet, whose origin stems from the circle, the pole/axis and the four directions. This [circle contains] thirty-six letters and captures the languages of [all] nations" (wa-huwa al-qalam al-țabīi wa-așluhu mustahrağ min al-dä̀ira wa-l-quțb wa-l-ğihāt al-arba'wa-huwa sitta wa-thalāthūn harfan wa-qad istau'aba ğamì luġāt al-umam). According to Dū al-Nūn, he copied this circle, which consists of three alphabets, from Hermes's temple. He further explains that this circle captures all the special spiritual attributes (al-hawāșs al-rūhāninya), because it is organized according to the natural elements, the stars, the zodiac signs and the lunar stations (Fig. 1) (Bisțāmī, 2016: 67-8). Later in his work, in the sixth chapter, Bisțāmī returns to the "natural alphabet." This time, he calls it "the alphabet of philosophy/wisdom" (qalam al-hikma) and attributes it to the sage Ardimus (see below) (Bisțāmī, 2016: 85-7). In the second book of the Pleasures, Bisțāmì comments that "this alphabet is composed of the natural traits of the upper and lower worlds, and was extracted by Ibn Sabiin [d. 669/1271]" (Bisțāmī, 2016: 123).14 This multiplicity of accounts may be perplexing, but it may also tell us something about the remarkable openness of the corpus on the attributes of the scripts/alphabets to different, not necessarily compatible accounts.

After his brief discussion of the "natural alphabet," Bisțāmī moves on to describe the differences between contemporary alphabets. He starts with the Arabic alphabet, which apparently serves as his yardstick. He mentions that Syriac, for example, "is like

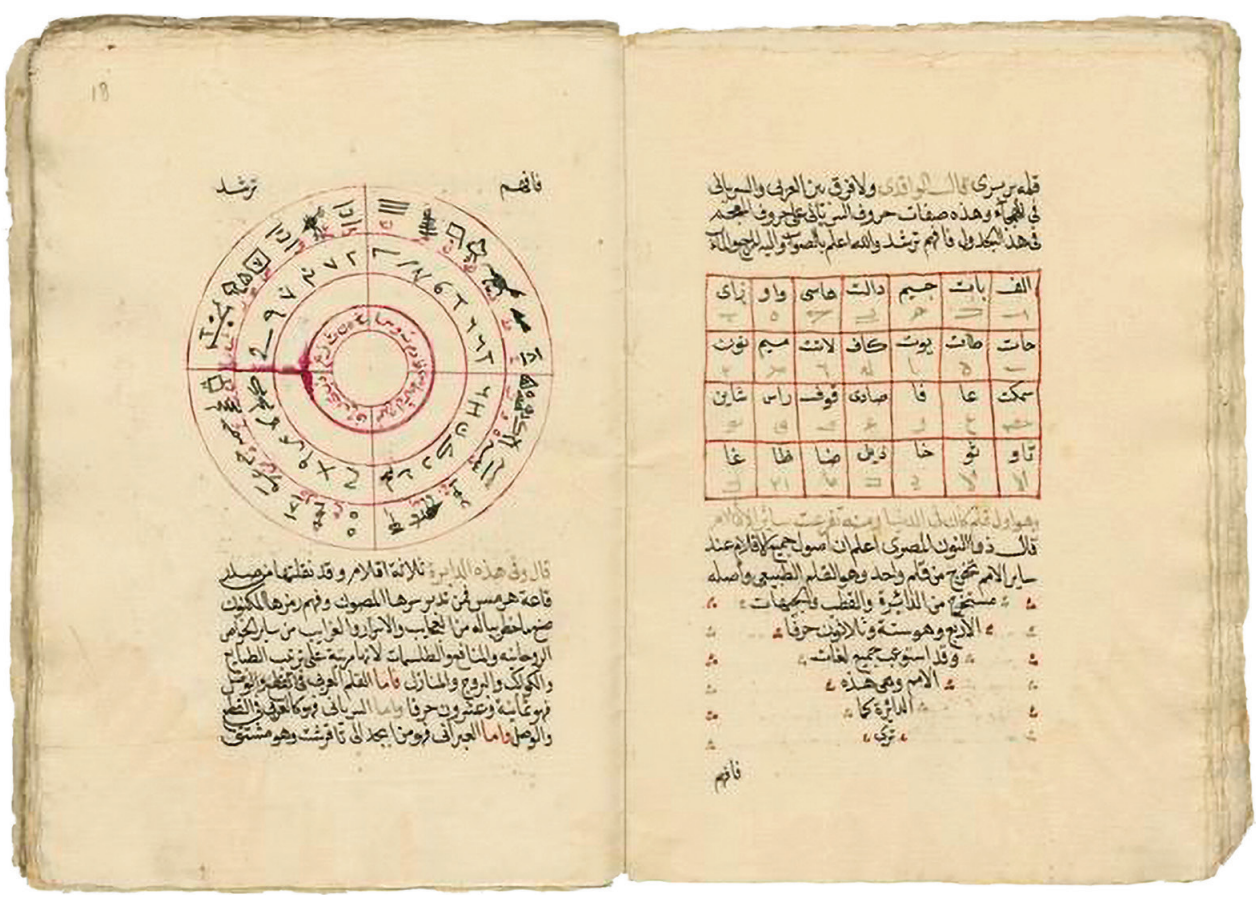

FIGURE 1

Mabāhiğ al-alām fìmanāhĭ̆ al-aqlām mimmā alqāhu rasūl al-ḥikma min hazāin al-raḥma, dated 1302/1885, ink on paper, Leiden, Leiden University Library, MS Or. 14.121, f. 18a

(C) LEIDEN UNIVERSITY LIBRARY 
Arabic in its connected and unconnected [letters]." The Hebrew alphabet follows the abğad order and is close to Syriac, but the Greek (Yünānī) is missing $h \bar{a}$ ', dāl, dẹa d, 'ain, $h \bar{a}$ and lām-alif, although, much like Ifrinğı and the Iștankilt (?) alphabets, it is close to Syriac. The Samaritan alphabet has eighteen letters and is missing the alif, $h \bar{a}$, $f \vec{a}$ ' and gain that the Hebrew has. He then moves on to discuss the special features of the Persian, Turkish, Mongol, Coptic, Latin (?) (Rūmī) and Armenian alphabets (Bisțāmī, 2016: 69-70). Importantly, despite minor mistakes, it is evident that Bisțāmī is referring here to alphabets that modern scholars may be able to identify. As will be discussed below, this is not always the case in the later parts of the Pleasures. Most importantly, his list of differences is intended to emphasize the similarities and compatibility among the alphabets.

After establishing the compatibility of the alphabets, Bisțāmī shifts his attention to the twenty-four alphabets, starting with Syriac (Süryānì), Adam's alphabet. The other alphabets are associated with other Quranic and/or biblical prophets and figures, such as Seth, Kenan, Idris, Noah, Shem, Japheth, Ham, Abraham, Isaac, Moses, Aaron, David, Solomon, Jesus, Simon, George and Daniel. Some of the alphabets are associated with certain languages - Chinese (ascribed to Japheth), Indian (ascribed to Ham), Hebrew (ascribed to Moses), Rūmī (ascribed to Jesus) and Armenian (ascribed to Daniel). The Arabic script is ascribed to the Prophet Muhammad, the Kufic alphabet to 'Alì b. Abī Ṭālib, the Iraqi script to Ḥusain b. 'Alī and the Berber to Muhammad b. al-Ḥasan b. 'Alī (Bisțāmī, 2016: 8o-1). Since most of the alphabets in this section - and, indeed, throughout the work - are compatible with the Arabic alphabet, each letter in these alphabets is attached to an Arabic one.

The sixth chapter is dedicated to the forty-one alphabets of the sages and past sultans/rulers. Certain alphabets, such as the Indian one, feature here as well, but they are different from the alphabets that appear in the fifth chapter. The first alphabet is the "natural alphabet," which, as has already been mentioned, is attributed to Ardimus. The letters of this alphabet are divided into four, each quarter corresponding to one of the four directions and the four Galenic humors. Bistāamī includes the illustration of the "natural alphabet" that he allegedly found in the fifteenth-century Maghribi shaykh

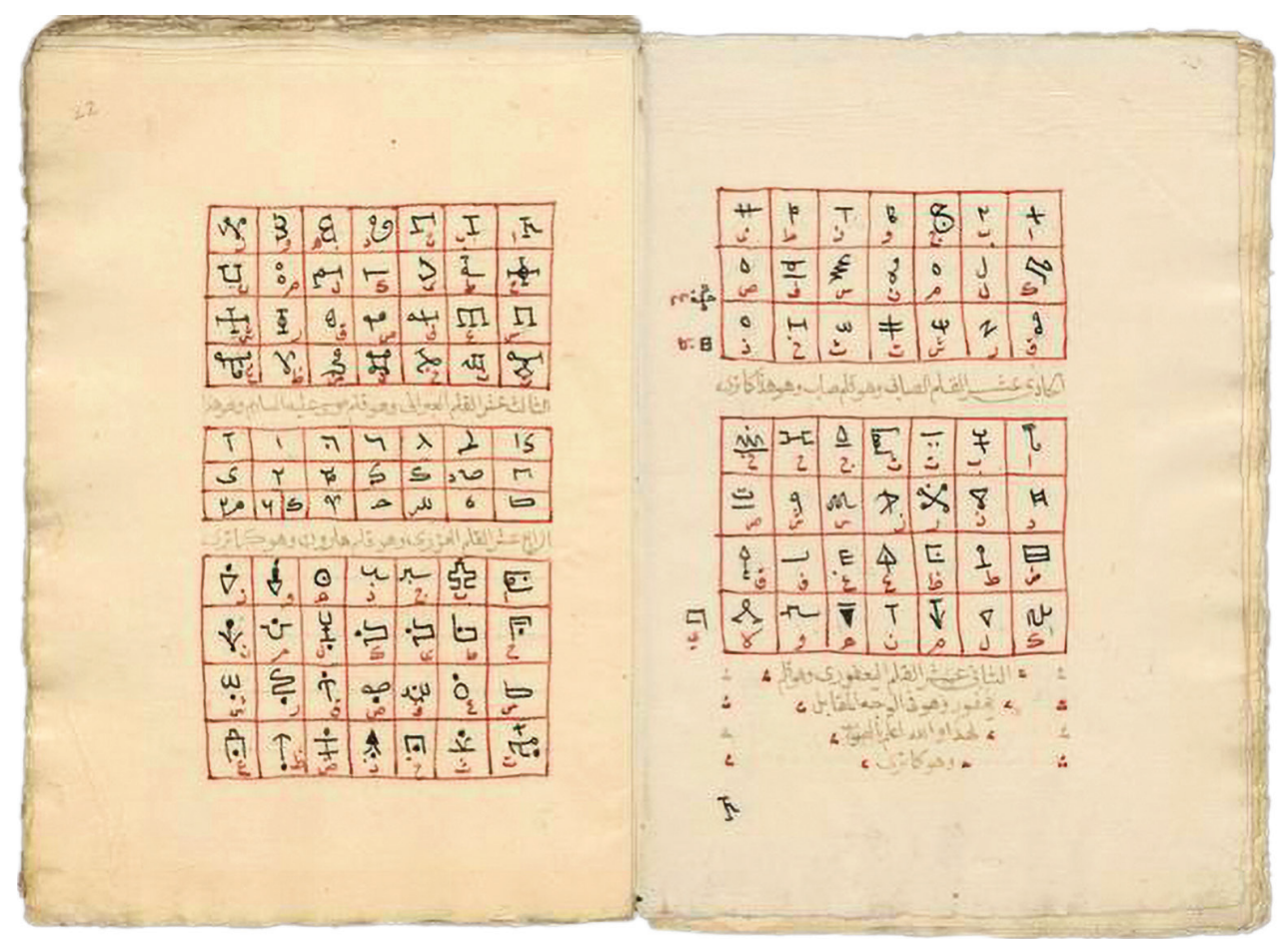

FIGURE 2 Bisțāmī, Mabāhiğ al-aclām fì manāhiğ al-aqlām mimmā alqāhu rasül al-ḥikma min hazā̉in al-rahma, dated 1302/1885, ink on paper, Leiden, Leiden University Library, MS Or. 14.121, ff. 21b-22a (C) LEIDEN UNIVERSITY LIBRARY 
Ya īš b. Ibrāhīm al-Umawī al-Andalusī’s (d. 903/1489?) The Manner of Agreement on the Composition of Magic Squares (Kaifìyat al-ittifāq fì tarkīb al-awfāq) (Fig. 2) (Bisțāmī, 2016: 86). ${ }^{15}$ Other alphabets in the chapter are attributed to pre-Islamic, Hellenistic or Indian figures, such as Plato, Galen, Hermes, Harish, Diquridus, Diqyanus, Qalfatrius, and the Byzantine emperor (al-malik al-Rūmì). In addition, there are several alphabets ascribed to Sufi masters, such as Ǧābir b. Hayyān al-Ṣūfī (d. 197/813) and Sa'd al-Dīn al-Hamawī (d. c. 658/126o). Another set of alphabets consists of aqlām attributed to groups, such as the Hurūfîs/Harfìs (qalam ba'd al-ḥukamā’min al-ḥarfìya), the sages of the West (qalam al-hukamā' al-Magrib) and "the alphabet of some scholars" (qalam ba'd al-'ulamä). Several alphabets are attributed to books, genres or disciplines: "the alphabet of the book The Sun of Secrets on the Science of the Virtuous (Šams al-asrār fi 'ilm al-abrār)," "the alphabet of the Greek philosophy" (qalam al-hikma al-Yūnānìya), "the alphabet of the Roman histories/chronicles" (qalam al-tawārih al-Rūmōya) and the "alphabet of the Coptic chronicles" (qalam al-tawārih al-Qibțȳa) (Bisțāmī, 2016: 83-104).

Much of the second book of the Pleasures, titled The Basis in Which the Letters That Are at Times Foundational and at Times Additional Are Described (al-qāंida tu'arraf bi-hā al-ḥurūf allatì taqi'a tāratan aṣtỹy wa-tāratan zāìda), is also devoted to a survey of alphabets. Bisțāmī opens his survey with the Indian alphabet (al-qalam al-Hindī), which "the astronomers (al-falakiyūn) use to compile their calendars and to calculate their figures" (Bisțāmī, 2016: 119). As the table that follows this explanation clarifies, the "alphabet" is in fact the Indian numerals, each of which is attached to a letter from the Arabic alphabet. However, Bisțāmī informs his reader, other peoples (aqwām) among the Indians adopted another alphabet.

After the Indian alphabet, Bisțāmī reproduces the Syriac (presumably the second most ancient alphabet?), and other alphabets that are equally ancient. He then moves on to the Greek (Yūnānì) alphabet, "the alphabet of the statue" (qalam haikal), "the royal alphabet" (qalam mulūkì), the Ifrinğ̄ alphabet and the Persian alphabet. Then Bisțāmī reproduces the "natural alphabet," which he attributes, as we have seen, to Ibn Sabiin. After the "strange Persian alphabet" (qalam Fārisì garīb), he includes the "written [?] alphabet" (qalam al-makhțūtì) and "Kufic alphabet," which looks very different from the Kufic alphabet in the previous sections of the work. To clarify, by "reproduction" I do not want to imply that the alphabets are the ones used by different historical linguistic communities, although occasionally this was clearly the case (as with the Kufic alphabet, for instance). Instead, "reproduction" refers to Bisțāmī's copying of tables he found in earlier sources.

For some of the alphabets, Bisțāmī adds a brief description. For the "ancient stone alphabet" (qalam hağrī qadìm), for instance, he comments that this is an alphabet used for talismans in Ard al-Sacid. In another instance, he reveals that he found some of the alphabets in books and chronicles. In other cases, Bisṭāmī claims to have copied alphabets he found on inscribed objects (such as talismanic bowls) and amulets he came across. For these alphabets, he suggests that the alphabets are linked to the purpose of the talismans, the amulet or to specific practices/bodies of knowledge. The Haktadi/ Hiktadī alphabet, for example, is derived from a book on the science of formations ('ilm al-takwīnāt) (Bisțāmī, 2016:113).

Under the title Sublime Alphabets Which Were Selected from Spiritual Books and Mysterious Works (aqlām ğalīla untuhibat min kutub rūhānīya wa-a'māl ġarība), Bisțāmī includes several alphabets that correspond to the nature of the planets $\left(t a b \bar{a}^{2} i^{c}\right.$ al-kawākib). Here, not only does he reproduce the alphabet but describes its use: "this is the greatest alphabet after the Arabic [one], [if] it is written with Saffron and rose water on Friday, at the hour of Venus (sā'at al-Zuhra) and the rise of the Pleiades, [the request] will be accepted, if God permits" (Bisțāmī, 2016: 141). ${ }^{16}$ Importantly, this example 
demonstrates the role of the alphabets in the talismanic compound. Moreover, it illustrates the specific talismanic attributes of each alphabet. However, in the Pleasures, only rarely does Bisțāmī elaborate on the specific talismanic qualities of the alphabets, as he does here.

Other alphabets in the Basis are ascribed to biblical/Quranic figures. In David's alphabet, Bisțāmī explains, the special characteristics of the Psalms (hawāsș al-Mazāmīr) are written (Bisțāmī, 2016: 137-8). Another alphabet is attributed to Āṣif b. Barhiyā, King Solomon's vizier (Bisțāmī, 2016:138). A further group of alphabets consists of those pertaining to notable figures, such as Hermes (or Hermeses, Harāmisa) (Bisțāmī, 2016: 142), various priests who served ancient kings (Bisțāmī, 2016: 148-9), or groups, such as the Basran Brethren of Purity (ihwwān al-șafä) (Bisțāmī, 2016: 147).

Bisțāmī also devotes a cluster in the Basis to the alphabets of the prophets (aqlām al-anbiy $\left.\vec{a}^{3}\right)$. He starts this survey with Idris's alphabet, as Idris was the one who "invented the Syriac alphabet and recorded with it (ațbata bihi) the sciences (ulüm) that were revealed to him (wa-mā anzala 'alaihi min al-wahy)" (Bisțāmī, 2016: 151). Bisțāmī then reproduces the alphabets of Šu'aib, Lot, Ṣāliḥ, Dhū al-Nūn (also known as al-qalam al-Ahmimì̄), George (Ğirğis, one of Jesus's disciples), Joseph, and Isräfil. Finally, he concludes the work with the alphabets of six sages (hukamä): Sukyayus, Ghilawus, Hilyabus, Hirjis, Qatarjis and Hermes (Bisțāmī, 2016: 154-6o).

Now that we have completed the survey of the Pleasures, a word is in order on the similarities between Bisțāmīs Pleasures and the long tradition of writing about the talismanic qualities of different alphabets. There are clear similarities between the Pleasures and earlier works, such as the Long-Desired Knowledge: the organization of the works around tables of comparable alphabets; the attribution of letters from the Arabic alphabet to equivalent letters in the other alphabets; and the attribution of alphabets to pre-Islamic (biblical and late antique) and Islamic authorities. Moreover, much like the Pleasures, the Long-Desired Knowledge stipulates a split between the Arabic alphabet (in the latter work, it is explicitly referred to as qalam 'Arabī) and other alphabets, including, as we shall presently see, the Kufic alphabet (Ibn Wahshīya, 2010: 41). In other words, both works - and the literature on the secret of the alphabets as a whole - insist that each alphabet, including those that are treated in other corpora and bodies of knowledge as different visual manifestations of the same letter (as is the case with the Kufic alphabet/script in relation to Arabic, for example), is indeed separate, each is traced back to a different origin and/or authority and, presumably, encapsulates a different set of talismanic qualities. At the same time, there are important differences: the Long-Desired Knowledge, for instance, attributes the Kufic alphabet to Ismāîl, "the first speaker and writer of Arabic," whereas Bisțāmī does not attribute it to any authoritative figure (Bisțāmī, 2016: 101; Ibn Waḥshīya, 2010: 45). ${ }^{17}$

The Long-Desired Knowledge is one of the earliest extant compilations in the corpus on the secrets of the alphabets. As we have seen, Bisțāmī refers in his encyclopedic work to at least one book dealing with this topic. It is also possible that Bisțāmī was familiar with al-Ğildakìs Pearl of the Diver, whose last folios are devoted to the talismanic attributes of numerous alphabets. Despite some discrepancies between the works, the similarities are striking. Much like Bisțāmī, al-Ǧildakī ascribes alphabets to Quranic/ biblical and late antique authorities and attaches a letter from the Arabic alphabet to corresponding letters in the other alphabets (Ǧildakī, Berlin Ms: 197a-209a). In other words, Bistāamìs Pleasures should be situated within the context of a long tradition that remains to be reconstructed.

By way of conclusion, I would like to dwell on the implication of the compatibility of the alphabets. As the reader may recall, each letter in any of the alphabets recorded in the Pleasures is matched to a letter from the Arabic alphabet. By extension, each letter 
in any alphabet can be matched to a parallel letter in any other alphabet. Moreover, if the letters in any alphabet match the letters of the Arabic alphabet, then each of these letters has a numerical value. Therefore, at least in theory, the same alphabetical divinatory techniques ( $\breve{g} a f r$ ) can be employed on all alphabets. Indeed, as Aslı Niyazioğlu has recently pointed out, the anonymous author of the fifteenth-century work The Hidden Pearl (Dürr-i meknun, written shortly after the Ottoman conquest of Constantinople in 857/1453, perhaps even during Bisțāmīs lifetime), when discussing the obelisk in the city's hippodrome, explains that "they had inscribed various images (süretler) on it. Through the science of alphabetical divination ('ilm-i cifr), they reveal the prophets and rulers who came and would come to this world, as well as those who would rule over this land" (Bican, 2009: 154). ${ }^{18}$ (Interestingly, he mentions that their dates or, perhaps, chronicles (tarihler) were written in Syriac (süryanca).) In this respect, Bisțāmī's Pleasures - and, more generally, the corpus of the secrets of the alphabets - reflects the sense of universalism shared by many practitioners of the science of letters, including other members of the Brethren of Purity network, such as Șa'in al-Dīn b. Turka (d. 830/1437) (Binbaş, 2016; Melvin-Koushki, 2012).

Interconnections: The Example of the Kufic and Ma'qilī Alphabets

Throughout this essay, I consider Bisțāmī as a narrative node connecting the literature on the alphabets/scripts, the inventory of the palace library, the manuscripts (and scrolls) containing invocations and the talismanic objects. While it is very difficult to demonstrate at this point that the creators of the manuscripts and objects, on the one hand, and the palace librarian, on the other, were familiar with Bisțāmì's work or with the corpus on the attributes of the alphabets/scripts more generally, there seems to be a remarkable degree of coherence across manuscripts and objects to suggest that this may have been the case. Additionally, there may have been other traditions and interpretations that informed calligraphic practices in the production of talismans. In her recent study of mirror writing in Islamic calligraphy (muthannā), Esra Akın-Kıvanç has suggested that mirror writing in general and on talismanic objects, such as talismanic shirts or panels with God's names, in particular was derived from certain Sufi traditions about mirrors, visions and sight (Akın-Kıvanç, 2020).

To illustrate the coherence across the inventory, the manuscripts, objects and theoretical/prescriptive writings about attributes of the alphabets/scripts, I would like to concentrate on the use of Kufic and Máqili alphabets/scripts. As we have seen in the previous section, Bisțāmì's works and other writings dealing with the attributes of the alphabets/scripts pay considerable attention to the Kufic alphabet. Turning to the inventory of the palace library, one of the items in the section on prayers, invocations, unique qualities of the Quran and magic squares in the palace library was an unbound volume containing the Beautiful Names of God in Kufic script/alphabet (al-Asmā’ al-husnā bi-hatț[in] Küf['̄yin] ġairu muğalladin) (Burak, 2019: 355). This is the only explicit mention of the Kufic script/alphabet in this section of the library. ${ }^{19}$ Several studies have noticed the use of "Kufic script" on talismanic objects. Most notably, M. Casanova (1921) and Venetia Porter (1998) have observed the use of "Kufic script" in magic seals. Porter has also pointed out that a similar script is mentioned in Ahmad al-Būnī's (d. c. 622/1225) The Sun of Gnosis. More recently, Yasmine Alsaleh has observed the use of floriated (and, to a lesser extent, angular) Kufic script in talismanic scrolls from the Fatimid (tenth to eleventh centuries) through the Mamluk (fourteenth century) periods (Alsaleh, 2014). Yet, it seems to me that this connection between "Kufic" and talismans/talismanic practices has remained understudied. The literature on the 
secrets of the alphabets, I would like to suggest, cast new light on the use of Kufic script/ alphabet in different talismanic compounds. In other words, it is possible that Kufic script was intentionally employed because of its talismanic qualities and its attribution to Ismāīil or, more frequently, 'Alī b. Abī Taalib.

The literature on the secrets of the alphabets in general and the case of the Kufic alphabet in particular draw attention to the systematic use of other scripts/alphabets in talismanic compounds. Consider, for example, the use of the Ma'qili script/alphabet, which is commonly referred to in modern literature as "square Kufic." The history of the script and its proliferation has been the subject of several studies (Majeed, 2006, 2013; Ritter, 2007-8), but most have not examined the use of Ma'qili ("square Kufic") script/alphabet in talismanic compounds. An important exception is Tehnyat Majeed's study of Mácilī inscriptions in Ilkhanid Isfahan and Mamluk Cairo, where she has suggested in passing that these inscriptions fulfilled talismanic functions (Majeed, 2006: 100-1, 175). By examining the use of Máqili script and its connection to the Kufic alphabet/script, I attempt to expand the logic I derived from the literature on the attributes of the alphabets/scripts to other scripts.

Few sources make the connection between Ma'qili and the "Kufic" alphabet which is mentioned in the talismanic/lettrist literature. Nevertheless, modern scholarship tends to use the term "square Kufic" quite loosely, often without dwelling on the "Kufic" connections to the Ma'qili alphabet. Several fourteenth- through sixteenth-century accounts, however, establish interesting connections between the alphabets/scripts. Šams al-Dīn Āmulī (d. 753/1352), for instance, relates in his encyclopedic compilation that the Kufic alphabet stemmed from Ma'qili, which was "the common script/alphabet among the Arabs in the old days" (dar ayyām-i mā taqaddam hatț-i mašhūr-i miyān-i 'Arab hatț-i Ma'qilì būd va ba'd az ān hațt-i Küfì bìrūn āmad) (Āmulī, 1891: 9; Faḍāīilī, 1971/1972: 162). And in his genealogy of calligraphers, the Safavid-era calligrapher Dust Muhammad Heravī (d. c. 971/1564) credits Yárub b. Qaḥtān, whom Dust Muḥammad identifies as the progenitor of the Arabs, with turning Ma'qili script into Kufic, making him its inventor, and 'Alī b. Abī Taalib its perfector (Roxburgh, 2001: 97). ${ }^{20}$ For Dust Muhammad, it seems, the Máqili served as the ur-alphabet from which other scripts/ alphabets diverged. It is also noteworthy that Dust Muhammad echoes views found in works on the secret of the alphabets, which attribute the Kufic alphabet to 'Alì b. Abī Țālib. ${ }^{21}$ Although Bisțāmī does not draw this connection between Máqilī and Kufic, given the popularity of Márili inscriptions across the eastern Islamic lands and the Maghrib, it might be possible to read the aforementioned accounts as reflecting a view that was not unique to the Persian-speaking lands.

The fairly frequent appearance of Ma'qili panels/alphabet and talismanic objects and manuscript copies, many of which are of texts included in the section of the palace library, may also point to the alphabet's/script's talismanic attributes. ${ }^{22}$ The closing bifolio of a Mamluk fifteenth-century copy of The Description of the Prophet (Șifat $a l-n a b \bar{\imath})$, which was apparently supposed to include the text of Abū al-Ḥasan al-Šādilī’s (d. 656/1258) Litany of the Sea (Hizb al-bahr), as the manuscript's title page suggests, ${ }^{23}$ contain two Ma'qili panels: the first (13b) was part of the original manuscript and is dated to $826 / 1422-3$, whereas the second panel (14a) may be a later addition, as it bears the name of Hair Bak (d. 928/1522), the Mamluk officer who became the first Ottoman governor of Egypt. Importantly, the Ma'qili panel (13b) appears under the heading "the Máqilī alphabet" (al-qalam al-Ma'qilì) (Fig. 3). Another fourteenth-century copy of the Litany, most probably created in the Mamluk lands, bears a Máqili panel (Fig. 4). Moreover, this practice continued well into the seventeenth century (if not later). A Mácilì panel also appears in the opening folio of a seventeenth-century Ottoman copy of the Litany, currently at the Walters Art Museum (Fig. 5). The Ma'qili alphabet/script 
FIGURE 3

Kitāb șifat al-nabīwa-Hizb al-baḥr attributed to al-šãdililī, made for al-Amïr Hair Bak, the governor of Egypt, copied and illuminated by Hāạiir b. Yūsuf al-Azharī, Egypt, probably 926/1519, $19 \times 13.5 \mathrm{~cm}$, ink on paper, Moscow, Mardjani Foundation, MS IM/R-1, ff. 13b-14a (C) MARDJANI FOUNDATION
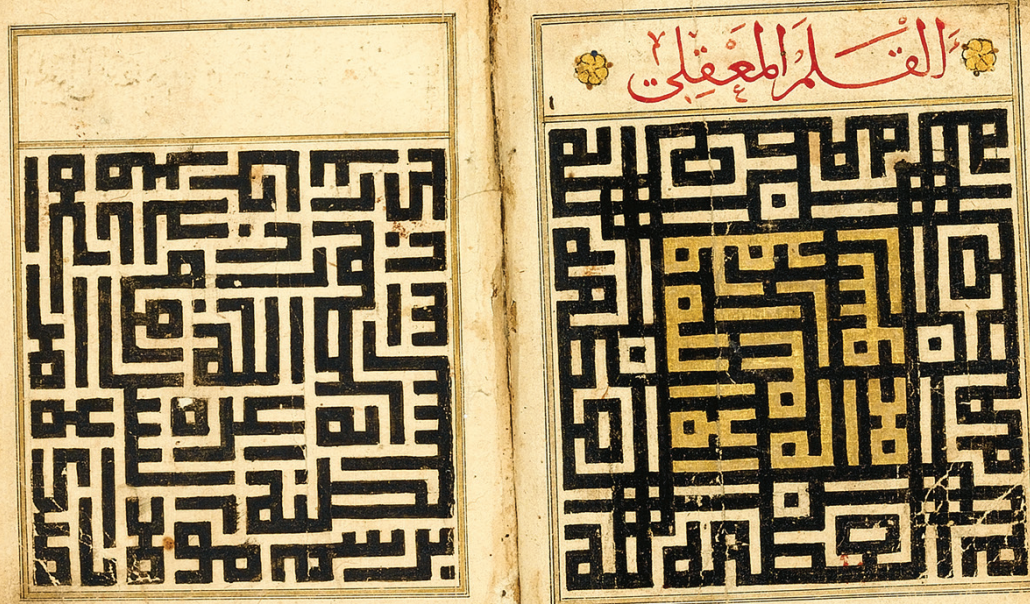

FIGURE 4

Hizb al-bahr, attributed to al-Šādilīi, Egypt or Syria, fourteenth century, $19.5 \mathrm{~cm}$ (height), ink on paper, Doha, Museum of Islamic Art, Ms.242.1999, f. $1 \mathrm{a}$

(C) MUSEUM OF ISLAMIC ART, DOHA

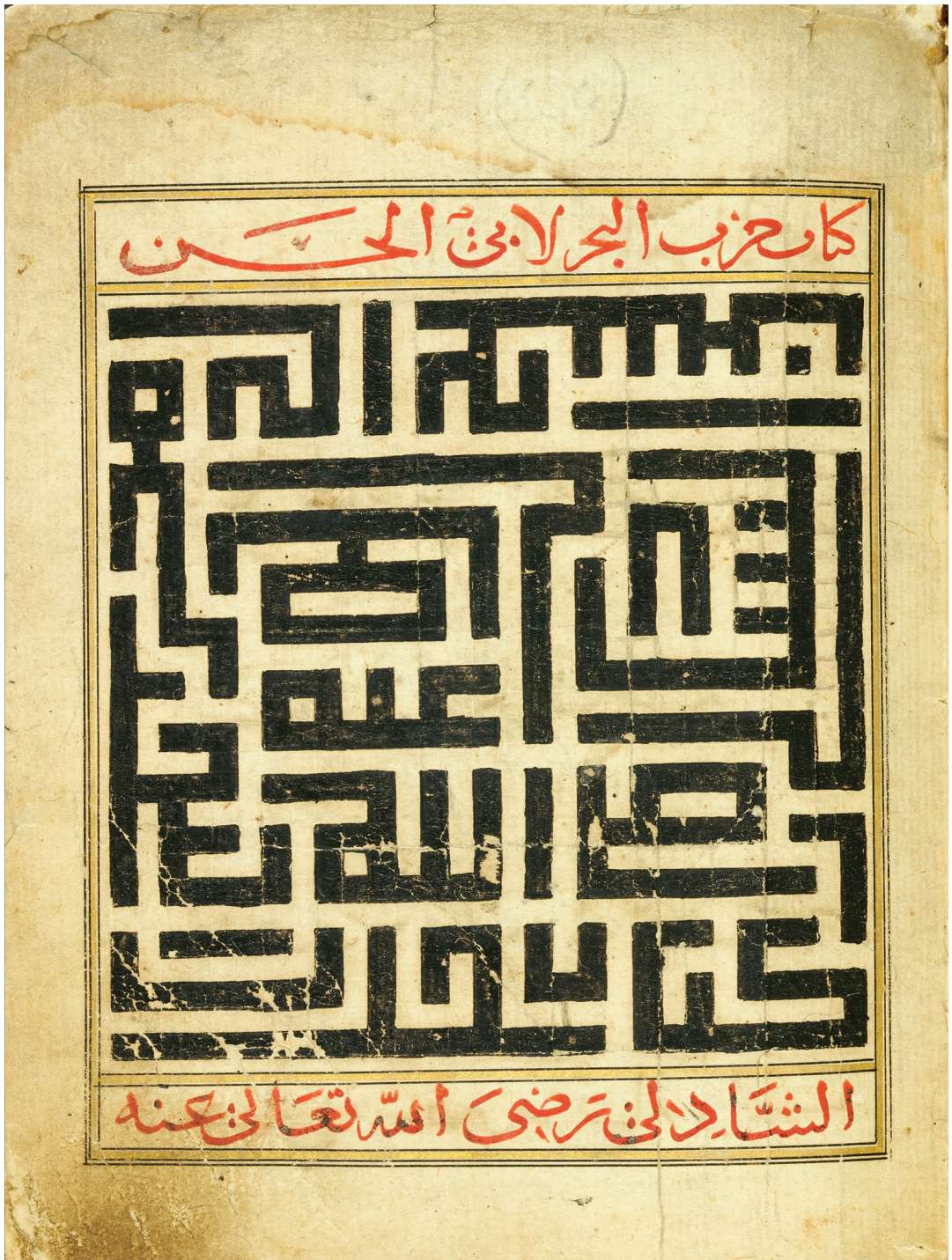

JOURNAL OF MATERIAL CULTURES IN THE MUSLIM WORLD 2 (2021) 32-54 


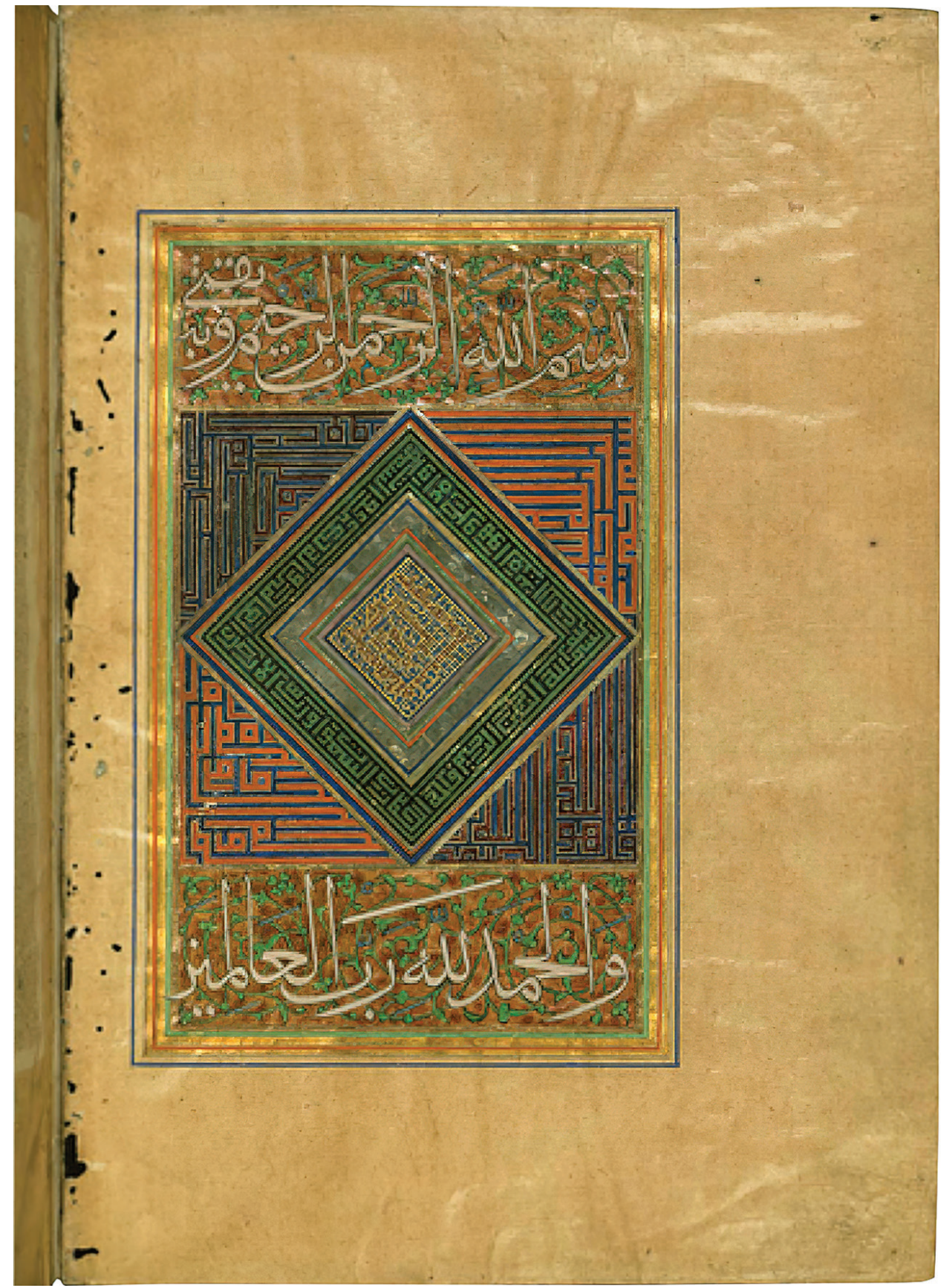

was also employed in two late fifteenth-century talismanic Quranic scrolls from Iran (Figs. 6 and 7), which may resemble the scrolls mentioned in the inventory.

As Majeed and others have noticed, Máqili panels were used in other media as well. Several decades after the panels had disappeared from buildings in the Mamluk domains, Máqilì panels or panels containing inscriptions in a style reminiscent of Ma'qili script/alphabet gained popularity in the core lands of the Ottoman Empire. A Ma'qili panel appears on the basis of the southwest minaret of Bayezid II's mosque in Istanbul (completed in 1506). ${ }^{24}$ In addition, also in the basis of the southwest minaret, an octagonal Ma'qilī panel made of green and red stone was installed. ${ }^{25}$ The latter panel's calligraphy seems to be a hybrid of the octagonal Kufic inscriptions, which were somewhat popular in the Mamluk lands and the Máqili script/alphabet. ${ }^{26}$ A similar pair of panels was installed above the entrance to Şehzade Mosque (completed in 1548, Fig. 8).
FIGURE 5

Hizb al-bahr, attributed to al-Šādilī, Ottoman lands, seventeenth century, $31.5 \times$ $21.5 \mathrm{~cm}$, ink and pigments on gold-sprinkled paper and tan tinted paper, Baltimore, Walters Art Museum, W.578, f. 7 B (C) WALTERS ART MUSEUM 
FIGURE 6

Quranic scroll, Iran, second half of the fifteenth century, $8.7 \times 744 \mathrm{~cm}$, ink, pigments and gold on paper, Dublin, Chester Beatty Library, Ms Is 1626

(C) CHESTER BEATTY LIBRARY

FIGURE 7

Quranic scroll, Iran, second half of the fifteenth century, $10.5 \times$ $1128 \mathrm{~cm}$, ink, pigments and gold on paper, Dublin, Chester Beatty Library, MS IS 1625

(C) CHESTER BEATTY LIBRARY

FIGURE 8

A pair of Ma'qilī panels was installed above the entrance to Şehzade Mosque, completed in 1548

(C) PHоTO BY THE AUTHOR
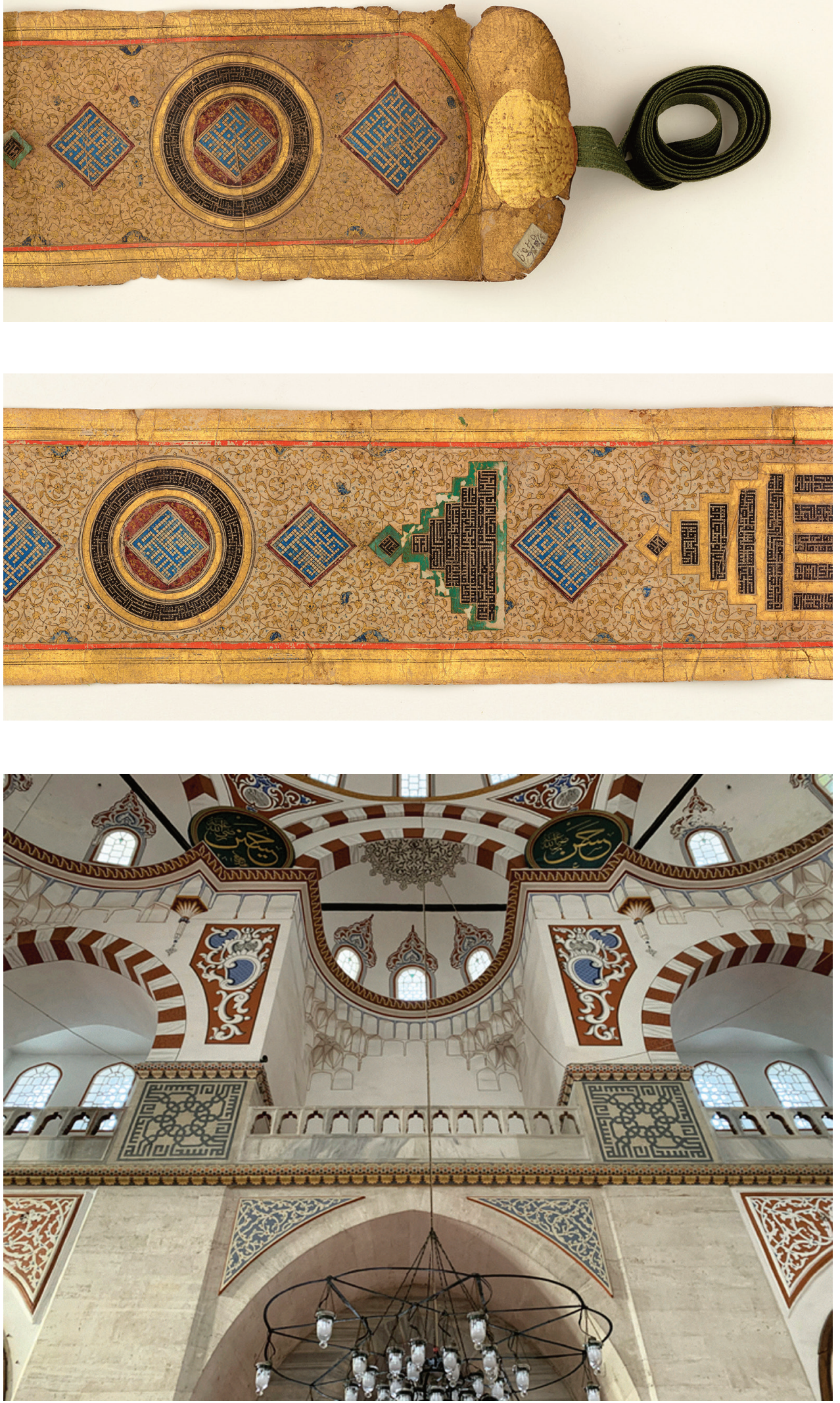

Ma'qil̄ panels adorn numerous other early sixteenth-century buildings: for example, at least two such panels were commissioned for the complex of Çoban Mustafa Paşa (d. 1529) in Gebze (completed in the 1520s and probably renovated in 1538). In addition to these panels, a floriated Kufic inscription was installed. ${ }^{27}$ Furthermore, sixteenth- and 


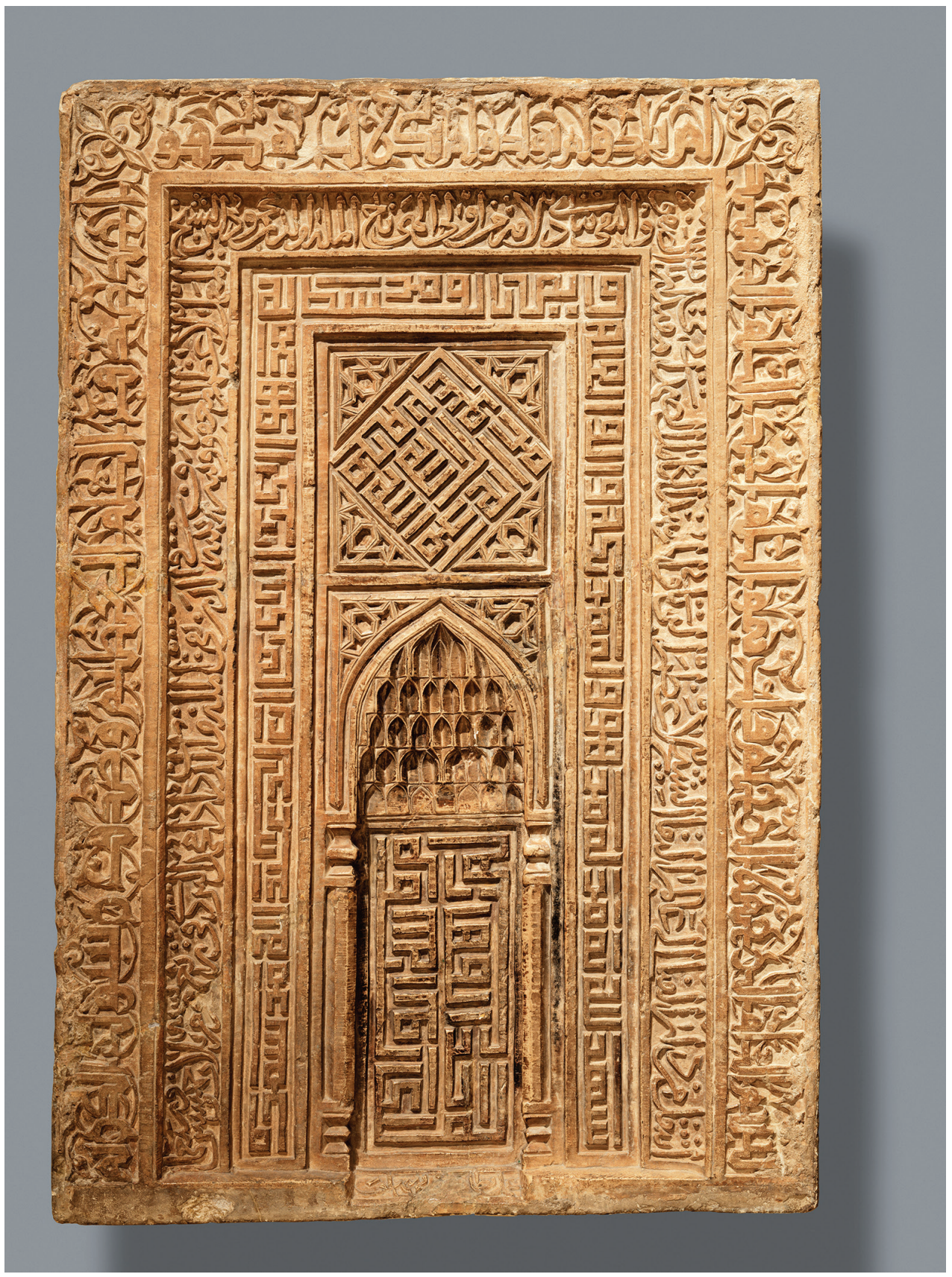

FIGURE 9

Tombstone in the form of an architectural niche, dated $753 / 1352,83.2 \times 55.3 \mathrm{~cm}$, carved marble, New York, Metropolitan Museum of Art, 35.120

(C) METROPOLITAN MUSEUM OF ART seventeenth-century talismanic shirts from the Ottoman lands are also inscribed with Máqili panels. ${ }^{28}$ The careful and calculated use and placement of these panels suggest that they were used for specific talismanic purposes.

As in the case of the Çoban Mustafa Paşa complex, there seems to have been a significant distinction between Ma' qil̄ and Kufic alphabets in the same historical setting. The distinction - or, perhaps, division of talismanic labor - between the Ma'qili and Kufic alphabets/scripts may also inform our reading of earlier inscriptions from other parts of the Islamic lands. A fourteenth-century engraved tombstone from Yazd (Iran) depicting an architectural niche, for example, incorporates various alphabets/scripts. While the doors, the panels above them and the closest frame are inscribed in Ma'qili, the outermost frame is inscribed in floriated Kufic (Fig. 9). ${ }^{29}$

To sum up, all these examples indicate that the selective use of Máqili and Kufic scripts/alphabets was intentional and calculated. Moreover, since the content of both the Máqili and Kufic inscriptions tends to contain Quranic verses, invocations or 
devotional expressions, it is quite likely that the alphabets/scripts were understood as talismanic in nature. ${ }^{30}$

\section{4 \\ "The Hand/Script/Alphabet of Yāqūt": The Talismanic "Calligrapher"}

One of the most important insights gained from the literature on the attributes of the alphabets/scripts is the split between the written letter in the text and the talismanic alphabet/script. Can this insight enrich the reading of other entries in the section on invocations, prayers, the special characteristic of the Quran, God's Beautiful Names and magic squares?

While I do recognize that an affirmative answer to this question is quite conjectural, I believe it is worth considering the literature on the talismanic attributes of the alphabets/scripts along with other Sufi-informed theoretical writings about letters as part of a semiotic repertoire that shaped "calligraphic" practices. Bayezid II's librarian meticulously recorded what seems like the "calligraphic style" in which the objects and volumes were inscribed or the identity of the calligrapher, be it Yāqūt al-Musta'șimī, Argiūn or Shaykh Hamdullah (d. 926/1520). As I have suggested in my preliminary study of the section, it is quite possible that 'Atufì believed that listing the calligraphers' name would please his patron, himself an accomplished calligrapher and disciple of the renowned calligrapher Shaykh Hamdullah. Indeed, some of the collections of invocations and prayer books were copied by skillful calligraphers, who were often familiar with stylistic conventions of other parts of the eastern Islamic lands. In some cases, colophons and front pages attribute works to famous calligraphers. The front page of a copy of The Invocations of the Seven Days (Ad'iya al-ayyām al-sab'a) that bears Bayezid II's seal and 'Atufì's description mentions Yāqūt al-Musta'ṣimī's student Mubārakshāh b. Quṭb (active late seventh or early eighth/thirteenth or fourteenth centuries) as the copyist (Fig. 10), whereas the colophon, which was apparently taken from another manuscript, attributes the copy to Yāqūt himself. ${ }^{31}$

The attribution of a manuscript to a renowned "calligrapher" raises questions concerning the translation of the Arabic phrase "bi-hațt." In my preliminary study of the section, I have translated the word as "in the hand of so-and-so." But, to follow the logic of the literature on the attributes of the alphabets/scripts, an equally appropriate translation may be "in the alphabet of so-and-so." It is possible that in the same manner that Bisțāmī attributed certain alphabets to prophets, sages and collectives, others, such as Bayezid II's librarian, attributed certain talismanic qualities to the alphabets of leading "calligraphers." If this reading is correct, it bears on the common use of the term "calligraphy" in the context of talismanic compounds. The literature on the secrets of the alphabets suggests that "calligraphic styles" are not simply different visual manifestation of the same (Arabic) alphabet, but completely different alphabets, each with its own talismanic qualities. These alphabets, in turn, are part of an interconnected, compatible network of alphabets. As we have seen, Bisțāmī and possible other authors in the tradition on the attributes of the alphabets/scripts associated certain scripts with specific corpora, texts and scholarly circles. Could it be that the same logic informed 'Atufi's description as he was going over the section in the library?

The literature on the attributes of the alphabets/scripts adds another dimension to the historiography of Islamic calligraphy, as it offers a considerably different perception of "calligraphy" from the one found in many treatises on calligraphy or biographical dictionaries of calligraphers. There are, however, interesting exceptions. One of them is the genealogy by Dust Muhammad I have mentioned above. In the Ottoman context, 


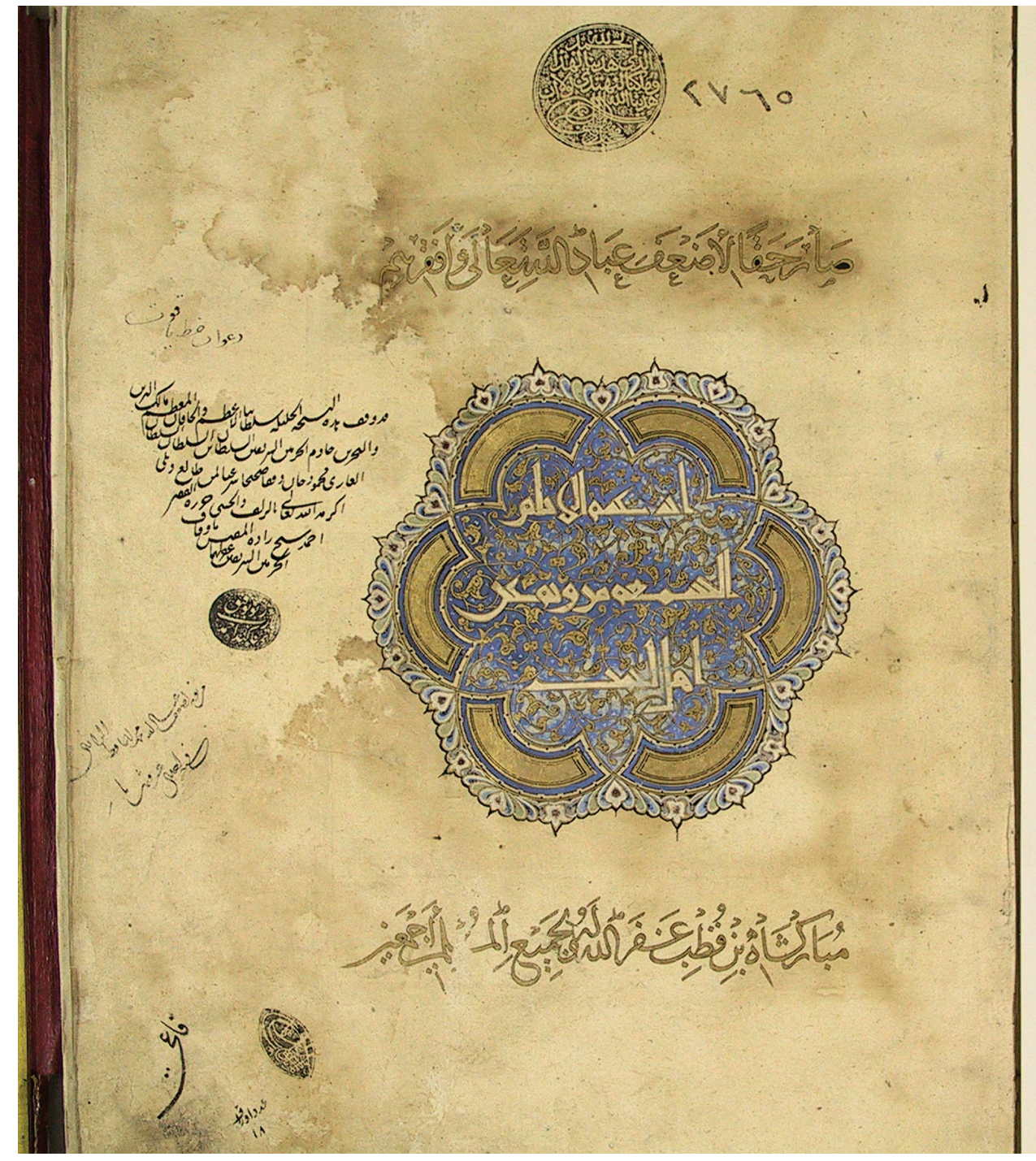

Mustafa 'Âli (d. 160o), in his Epic Deeds of Artists (Menākib-i hüner-verān), also echoes the literature on the secrets of letters:

Now, the first of those scripts[/alphabets] is the Arabic script[/alphabet], and it is that script[/alphabet] which is still in use among the Arabs, Persians, and people of Rum and Daylam. The second is the Kufic script[/alphabet]. Before the Hijra, the most widely used script[/alphabet] was this one. Its letters were slightly more well-defined than the Arabic type. The third is the "natural" script[/alphabet]. It is this script that the masters of miniature writing (ashāb-ı ufāk), [that is,] talisman writers and other astronomers/astrologers, have been using. The fourth one is the script[/alphabet] of Hermes the philosopher. He is the revered prophet known as Armiya the First [Jeremiah] or, according to some, the Prophet Idris [Enoch]. This was probably the earliest script[/alphabet]. The fifth [is] the Qalfatīnī script [/alphabet]. The sixth is the script[/alphabet] of the sages (kalem-i hukema $)$. The seventh is the script[/alphabet] of secrets (kalem-i esrär). The eighth is the hidden script[/alphabet] (kalem-i meknün). The ninth is the alluding [?] script[/alphabet] (kalem-i işāre). The tenth is the Syriac script[/alphabet] (kalem-i Süryānī). The eleventh is the clay script[/alphabet] (kalem-i fatīi $\bar{\imath})$. The twelfth is the script
FIGURE 10

Ad'iya al-ayyām al-sab'a, attributed to Yāqūt al-Musta'șimī and Mubārakshāh b. Quṭb, Baghdad (?), 68o/1281-82, ink and pigments on paper, Istanbul, Süleymaniye Library, Ms Ayasofya 2765 , $1 \mathrm{a}$ (C) SÜLEYMANIYE LIBRARY 
[/alphabet] of Joseph the soothsayer. The thirteenth is the Persian script[/alphabet] (kalem-i Fārsī). The fourteenth is the reyhānī script[/alphabet]. The fifteenth is the Greek script[/alphabet] (kalem-i Yünānì). The sixteenth is the Coptic script [/alphabet] (kalem-i Kıbtī). The seventeenth is cuneiform [?] (kalem-i mìh). The eighteenth is the Slavic script[/alphabet] (kalem-i Sakalibì).

$$
\text { 'ÂLI, 2011: 171-2, 298-9 }
$$

Later in the Epic Deeds, Mustafa 'Âli turns to discuss Imam 'Alī and his relationship to the Kufic script/alphabet: "His excellency [Imam] 'Alī, on account of his efforts in calligraphy, his attainment in the Kufic script/alphabet that outshined others ... He is especially noteworthy for his exalted fame and brilliant mastery of the Kufic script, which was several degrees superior to the writing of the Chosen Imam Hasan, and the sultan of the blessed martyrs, Imam Ḥusayn of Karbala" ('Âli, 2011: 180-1, 306). Additionally, Mustafa 'Âli records an account that he reportedly found in "an Arabic book that this servant once saw," linking 'Alī to the masters of the "six styles": "It was Ibn Muqla [d. 327/939] who first Arabicized the Kufic style, then Ibn al-Bawwāb refined it, and then Yāqūt al-Mustașimìi perfected it and he standardized it by listing all its regulations" ('Âli, 2011: 196, 322). In other words, according to this account, all the "calligraphic scripts/hands" emerged from the Kufic. It may also suggest that all these scripts/hands/ alphabets retained some of the talismanic qualities of the Kufic alphabet. Interestingly, Mustafa Âli interprets the use of different scripts/alphabets in talismans as an attempt at concealing the secret meaning from unworthy or uninitiated persons. He explains that "there were some who, by writing a talisman in three of four scripts[/alphabets] in order to make it seem confusing and contradictory, hid its secret meaning like a secret treasure protected by a spell" ('Âli, 2011: 170, 298). Bisțāmī, on the other hand, believed that each alphabet had its own talismanic qualities. Be that as it may, Mustafa 'Âli's comment points to the significance of using multiple alphabets in talismanic inscriptions. As Lale Uluç has recently argued, talismanic scrolls incorporated multiple "calligraphic styles" or alphabets (see also the fifteenth-century talismanic scrolls, Figs. 6 and 7). ${ }^{32}$ Again, this multiplicity of "calligraphic styles"/alphabets may point to a division of talismanic labor among them.

This essay has been an attempt to cast light on underexamined perceptions of the "calligraphic" style employed in the production of talismanic objects and manuscripts by reading the section on invocations, prayers, the unique qualities of the Quran and magic squares in the palace library of Bayezid II along with the work on the attributes of the alphabets/scripts. By taking the inventory as a document of practice, this exercise, I would suggest, illustrates the importance of paying attention to other elements of the talismanic compound, such as the alphabets/scripts employed.

It is important to stress that this reading does not preclude other interpretations to calligraphic practices and conventions. Furthermore, this essay does not purport to offer a single comprehensive explanation to talismanic writing. In a recent study, Esra Akın-Kıvanç has shown that mirror writing was frequently employed for the same texts (such as God's Beautiful Names) and objects (such as talismanic shirts and inscriptions). Akın-Kıvanç offers an interpretation of this practice that is derived from other Sufi traditions (Akın-Kıvanç, 2020). This essay joins her study to expand the range of interpretations often attributed to Islamic "calligraphy." 
Finally, I have tried to situate these practices in their broadest context. Much like Bisțāmì's career and intellectual genealogies, the practices and doctrines examined in the previous pages can be found from the Islamic Far West to the eastern lands. Indeed, while it may be difficult to reconstruct a coherent chain of transmission or genealogy of some of the perceptions of the different alphabets, their echoes can be found from tenth-century Andalusia to very recent times. In this sense, this exploration of the section from the palace library may inform the interpretation of a much broader range of Islamicate talismanic practices, well beyond the Mamluk sultanate and the Ottoman domains of the fifteenth century.

\section{About the Author}

Guy Burak is the Librarian for Middle Eastern, Islamic and Jewish Studies at NYU's Elmer Holmes Bobst Library. He is the author of The Second Formation of Islamic Law: The Hanafi School in the Early Modern Ottoman Empire (Cambridge University Press, 2015). In addition to articles on Ottoman legal history, he has published several studies on Islamic devotional texts.

\section{Bibliography}

Adle, C. (1996). Dust Muhammad Harevi. In: Encyclopedia Iranica, www.iranicaonline.org/articles/ dust-mohammad.

Akın-Kivanç, E. (2020). Muthanna/Mirror Writing in Islamic Calligraphy: History, Theory, and Aesthetics. Bloomington: Indiana University Press.

'Âli, M. (2011). Mustafa Âli's Epic Deeds of Artists: A Critical Edition of the Earliest Ottoman Text about the Calligraphers and Painters of the Islamic World. Edited, translated and commented by Esra Akın-Kıvanç. Leiden: Brill.

Alsaleh, Y.F. (2014). "Licit Magic": The Touch and Sight of Islamic Talismanic Scrolls, PhD Dissertation, History of Art and Architecture and Middle Eastern Studies, Harvard University.

Āmulī, Š.D.M.i.M. (1891). Nafầis al-funūn fí 'aräìs al-'uyūn. 2 vols. Tehran: Kārhāna-i Muḥammad Ḥusain Karbalāīi

Asrär al-aqlām (n.d.). Süleymaniye Library ms Fatih 3664.

Atbaş, Z. (2019). Artistic Aspects of Sultan Bayezid II's Book Treasury Collection: Extant Volumes Preserved at the Topkapı Palace Museum Library. In: G. Necipoğlu, C. Kafadar and C.H. Fleischer, eds., Treasures of Knowledge: An Inventory of the Ottoman Palace Library (1502/31503/4), Volume 1, Leiden: Brill, pp. 161-211.

Ben Azzouna, N. (2018). Aux origines du classicism: Calligraphies et bibliophiles au temps des dynasties mongoles (Les Ilkhanides et les Djalayirides 656-814/1258-1411). Leiden: Brill.

Bican, A. (2009). Dürr-i Meknûn: Inceleme, Çevriyazı, Dizin, Tıpkıbasım. Istanbul: Akademic Kitaplar.

Binbaş, İ.E. (2016). Intellectual Networks in Timurid Iran: Sharaf al-Dīn Alī Yazdī and the Islamicate Republic of Letters. Cambridge and New York: Cambridge University Press.

Bisțāmī, 'A.R.i.M. (2016). Mabāhiğ al-a lām fì manāhiğ al-aqlām mimmāa alqāhu rasūl al-ḥikma min hazā̄in al-rahma. Beirut: Dār al-Mīzān.

Bisțāmī, 'A.R.i.M. (n.d.). Bahrr al-wuqūf fì ilm al-awfāq wa-l-hurūf. Firestone Library, Princeton MS Islamic Manuscript, Third Series 614.

Bisțāmī, 'A.R.i.M. (n.d.). al-Fawāìh al-miskīya wa-l-fawātih al-Makkīya. Süleymaniye Library Ms Esad Efendi 1612. 
Bisțāmī, 'A.R.i.M. (n.d.) Mabāhiğ al-a lām fìmanāhiğ al-aqlām mimmā alqāhu rasūl al-ḥikma min hazǟin al-raḥma. Leiden Ms Or. 14.121.

Burak G. (2019). The Section on Prayers, Invocations, Unique Qualities of the Qur'an, and Magic Squares in the Palace Library Inventory. In: G. Necipoğlu, C. Kafadar and C.H. Fleischer, eds., Treasures of Knowledge: An Inventory of the Ottoman Palace Library (1502/3-1503/4), Volume 1, Leiden: Brill, pp. 341-66.

Casanova, M. (1921). Alphabets Magiques Arabes. Journal Asiatique 18, pp. 37-55.

Ebstein, M. (2014). Dū l-Nūn al-Mișrī and Early Islamic Mysticism. Arabica 61, pp. 559-612.

El-Daly, O. (2015). Egyptology: The Missing Millennium: Ancient Egypt in Medieval Arabic Writings. London: Routledge.

Faḍāīlī, H.A. (1971/1972). Ațlas-i Hatṭ. Tehran: Kitābfurūšī Šahrīyār.

Faure, A. (2012). Ibn Sabīn. In: Encyclopaedia of Islam, Second Edition, https://referenceworks .brillonline.com/entries/encyclopaedia-of-islam-2/ibn-sabin-SIM_3342?lang=en.

Fleischer, C.H. (2009). Ancient Wisdom and New Sciences: Prophecies at the Ottoman Court in the Fifteenth and Early Sixteenth Centuries. In: M. Farhad and S. Bağci, eds., Falnama: The Book of Omens, Washington: Arthur M. Sackler Gallery, pp. 232-43, (notes) 329-30.

Fleischer, C.H. (2019). Learning and Sovereignty in the Fifteenth and Sixteenth Centuries. In: G. Necipoğlu, C. Kafadar and C.H. Fleischer, eds., Treasures of Knowledge: An Inventory of the Ottoman Palace Library (1502/3-1503/4), Volume 1, Leiden: Brill, pp. 155-6o.

Gardiner, N. (2017). The Occultist Encyclopedism of 'Abd al-Raḥmān al-Bisțāmī. Mamluk Studies Review 20 , pp. 3-38.

Gardiner, N. (2019). Books on Occult Sciences. In: G. Necipoğlu, C. Kafadar and C.H. Fleischer, eds., Treasures of Knowledge: An Inventory of the Ottoman Palace Library (1502/3-1503/4), Volume 1, Leiden: Brill, pp. 735-65.

Ğildakī, 'I.D.i.A. (n.d.). Durrat al-ġawwāṣ wa-kanz al-ihtișāṣ fi 'ilm al-hawāșṣ. Staatsbibliothek zu Berlin Ms Landberg 157.

Grenier, C. (2018). Reassessing the Authorship of the Dürr-i Meknūn. Archivum Ottomanicum 35, pp. 1-19.

Hämeen-Anttila, J. (2006). The Last Pagans of Iraq: Ibn Wahshiyya and His Nabatean Agriculture. Leiden: Brill.

Ibn Waḥshīya al-Nabațī (2010). Šauq al-mustahāmfı̀ma'rifat rumūz al-aqlām. Edited by Ğ. Ğum‘a. Beirut: Manšūrāt al-Jamal.

Kastritsis, D. (2012). The Şeyh Bedreddin Uprising in the Context of the Ottoman Civil War of 1402-13. In: A. Anastasopoulos, ed., Political Initiatives "From the Bottom Up" in the Ottoman Empire: Halcyon Days in Crete VII [a symposium held in Rethymo on January 9-11, 2009], Rethymo: Crete University Press, pp. 233-50.

Keskiner, B. (2016). The Octagonal Kufic Inscriptions in the Qartawiyya Madrasa and Its Counterpart in the Sultan Ahmed Mosque. In: A. Ohta, J.M. Rogers and R.W. Haddon, eds., Art, Trade and Culture in the Islamic World and Beyond: From the Fatimids to the Mughals, Studies Presented to Doris Behrens-Abouseif, London: Gingko Library, pp. 86-91.

Majeed, T. (2006). The Phenomenon of the Square Kufic Script: The Cases of İlkhānid Ișfahān and Bahrī Mamlūk Cairo, PhD Dissertation, Faculty of Oriental Studies, University of Oxford.

Majeed, T. (2013). Ma'qilī Inscriptions on the Great Mosque of Mardin: Stylistic and Epigraphic Contexts. In: M. Gharipour and İ.C. Schick, eds., Calligraphy and Architecture in the Muslim World, Edinburgh: Edinburgh University Press, pp. 363-78.

Mamaqānī, 'İ.Ṣ. (2019). Hurūf-i ramzī dar farhang va tamaddun-i ìrān. Tehran: Pāzīna.

Melvin-Koushki, M.S. (2012). The Quest for a Universal Science: The Occult Philosophy of Șāin al-Dīn Turka Ișfahānī (1369-1432) and Intellectual Millenarism in Early Timurid Iran, PhD Dissertation, Faculty of the Graduate School, Yale University.

Minorsky, V. (1959). Calligraphers and Painters: A Treatise by Qāḍ̄ Aḥmad, Son of Mīr-Munshī (circa A.H. 1015/A.D. 1603). Washington: Freer Gallery of Art. 
Necipoğlu, G., Kafadar, C., and Fleischer, C.H., eds. (2019). Treasures of Knowledge: An Inventory of the Ottoman Palace Library (1502/3-1503/4) (2 vols). Leiden: Brill.

Porter, V. (1998). Islamic Seals: Magical or Practical? In: A. Jones, ed., University's Lectures in Islamic Studies 2. London: Altajir World of Islam Trust, pp. 135-51.

Porter, V., Saif, L., and Savage-Smith, E. (2017). Medieval Islamic Amulets, Talismans, and Magic. In: F.B. Flood and G. Necipoğlu, eds., A Companion to Islamic Art and Architecture, Volume 1, Hoboken: John Wiley and Sons, pp. 521-57.

Ritter, M. (2007-8). Monumental Epigraphy in Iran: Paired Panels with Square Kufic Script and Sa'di Verses in Safavid and Earlier Islamic Architecture. Eurasian Studies 6, pp. 19-37.

Roxburgh, D.J. (2001). Prefacing the Image: The Writing of Art History in Sixteenth-Century Iran. Leiden: Brill.

Tezcan, H. (2011). Topkapı Sarayı Müzesi Koleksiyonundan Tılsımlı Gömlekler. Istanbul: Timaş.

\section{Notes}

1 Numerous interlocutors contributed in various ways to this essay. The works of Noah Gardiner and Matthew Melvin-Koushki have been indispensable. I would like to thank Barry Finbarr Flood, Khaled Malas, Cemil İrvin Schick, Gülru Necipoğlu, Lale Uluç, Galina Lasikova, Marinos Sariyannis and the participants in the GHOST workshop held in Istanbul in December 2019. Special thanks to Aslı Niyazioğlu, who patiently and generously read and commented on numerous drafts of this essay. Finally, I would like to thank the reviewers and the editors for their comments and suggestions. Recently, 'Īsā Șafarī Mamaqānī mentioned the Pleasures in his study of the long history of the occult alphabets in Iran (Mamaqānī, 2019: 69-73).

3 On the revolt, see Kastritsis (2012).

4 See Gardiner (2017) and the bibliography therein.

5 Bisțāmì devotes the third chapter ( faṣl) of the first book of his Pleasures to the science of letters and magic squares (Bisțāmī, 2016). For Bisțāmī's classification of the science, see Bisțāmī (Ms Esad Efendi: 14a-15a). For the chapter on the alphabets, see ibid. (78a-8ob).

6 For the purpose of this study, I have relied on the recently published edition of the Pleasures (Bisțāmī, 2016) and the Leiden copy of the work (Bisțāmī, Leiden Ms).

7 On the misattribution of the Long-Desired Knowledge to Ibn Wahshīya, see Hämeen-Anttila (2006: 21n45). Several studies have discussed the Long-Desired Knowledge. See, for instance, El-Daly (2015); Porter et al. (2017: 2-18).

8 Bisțāmī was familiar with Ibn Waḥshīya's Book of Great Magic (Kitāb al-siḥr al-kabīr) (Binbaş, 2016: 105).

9 Apparently, the work, titled The Meeting Place of Drawn Alphabets and the Fountain of the Secrets of Wisdom (Mağma' al-aqlām al-rasmīya wa-manbac al-asrār al-hikmīya), has not survived. See Gardiner (2017: 32).

10 Wa-mā ba'd dhālika min tabāyun al-ḥurūf min al-matāìb (?) wa-l-ta'rīfāt wa-l-murādāt. In both the Leiden ms and the published edition, the phrase is min al-matāit wa-l-tárîfät wa-l-murādāt. It appears that matäit is a scribal error.

11 In the Leiden MS and the printed edition, the word is al-kitāb. However, it is quite likely that Bisțāmī means the "author"/"writer" (kātib). This reading is supported by Bisțāmī's reference to the "written" (maktūb) a few sentences later.

12 In some cases, there are overlaps between the two books, at least in terms of the titles ascribed to different alphabets. There are, for instance, several Syriac alphabets throughout the Pleasures.

13 On Dū al-Nūn al-Mișrīi, see Ebstein (2014).

14 On Ibn Sabinn, see Faure (2012).

15 On Bisțāmī's study of the work, see Melvin-Koushki (2012: 242). The work was also consulted by al-Būnī (Gardiner, 2017: 23).

16 Similarly, Bisțāmī informs his readers: "Another alphabet for the acceptance (qabūl) [by God] and [for the attainment] of grandeur, from the Book of King Yus, which is in Arabic (wa-huwa bi-lisān $a l-A r a b$ ): if the name you want is written on parchment made from gazelle's skin [in this alphabet], it [will facilitate] acceptance [by God] and grandeur" (Bisțāmī, 2016: 141).

17 An anonymous pre-eighteenth-century work on the secrets of the alphabets attributes the Kufic alphabet to 'Alī (Asrār al-aqläm, n.d.: 1b). 
Cited in Aslı Niyazioğlu, "Urban Talismans and Early Modern Istanbul," paper presented at the Nature and Supernatural in Ottoman Culture workshop, Istanbul, December 2019. On the authorship of Dürr-i Meknûn, see Grenier (2018).

19 Kufic script/alphabet is mentioned in the section devoted to the Qurans (Necipoğlu et al., 2o19: 2:12, 16).

20 On Dust Muhammad Harevī, see Adle (1996). 'Abdallāh al-Ṣairafì (d. after 1345 or 1346) also establishes genealogical relationships between Máqilī and Kufic and attributes the latter to 'Alī b. Abì Ṭālib (Ben Azzouna, 2018: 426). Similarly, Qāọī Aḥmad (d. c. 16o3) consider 'Alī the perfector of Kufic script (Minorsky, 1959: 53-4).

21 See, for instance, the aforementioned anonymous treatise on the secrets of the alphabets (Asrār al-aqläm, n.d.: ib).

22 Numerous copies of the Litany of the Sea were included in the section of the palace library (Burak, 2019).

23 I thank Galina Lasikova of the Mardjani Foundation for the information about the manuscript, which I was not able to consult in person.

24 At the basis of the southwest minaret a Máqili carved stone panel reads "Praise be to God" (al-hamd li-Allāh): https://archnet.org/media_contents/8657.

25 See https://archnet.org/media_contents/8656.

26 See also Keskiner (2016). For an example of a fourteenth-century Mamluk octagonal Kufic panel, see Museum of Islamic Art, Cairo, no. 2077.

27 See https://archnet.org/media_contents/74547.

28 See, for instance, Tezcan (2011: $76-9,114-17)$.

29 The curvilinear cursive inscriptions provide clues to its history. In the middle framing band are the name and titles of Shaykh Maḥmūd b. Muḥammad, who died on February 21, 1352.

30 In some cases, however, the Máqilī inscriptions contained poetry or worldly content. See, for example, Ritter's study of the Ma'qili panels from Safavid Iran (Ritter, 2007-8).

31 Simon Rettig is currently completing a study of this manuscript. Ad'iya al-ayyām al-sab'a, Süleymaniye Library MS Ayasofya 2765 .

32 Personal correspondence. 